\title{
Multiple Successful Pregnancies Following Fertility-Sparing Surgery for Advanced Ovarian Cancer
}

John L. Powell*, Kotwall CA and Shiro BC

Departments of Obstetrics and Gynecology, New Hanover Regional Medical Center, Wrightsville Beach, North Carolina, USA

\begin{abstract}
Juvenile Granulosa Cell Tumors (JGCTs) of the ovary are rare. They usually present in children and adolescents. About $90 \%$ are diagnosed in early stage (FIGO I) with a favorable prognosis. More advanced stages (FIGO II-IV) usually have a poor clinical outcome. We report a case of long-term survival of a teenager with Stage III JGCT treated with aggressive debulking and thorough staging, but conservative surgery relative to the uterus, contralateral uninvolved ovary, and fallopian tube, plus combination chemotherapy. Her tumor recurred twice, 18 months and 17 years later, for which she had two additional surgeries and more chemotherapy. Because of the fertility sparing surgery, she was able to achieve 3 pregnancies and 4 children.
\end{abstract}

Keywords: Ovary; Granulosa cell tumor; Ovarian cancer

\section{Introduction}

Juvenile granulosa cell tumor (JGCT) is one of the rare sex-cord stromal tumors of the ovary occurring in the first two decades of life [1]. It makes up less than $5 \%$ of ovarian tumors in childhood and adolescence. It is different from the adult granulosa cell tumor seen in older women with respect to clinical and pathologic features, as well as biologic behavior [2]. The majority of JGCTs (90\%) is in FIGO Stage I and has a favorable prognosis when treated with surgery alone; however, the prognosis for advanced stage JGCT is usually poor, with only isolated case reports of successful surgery, plus combination chemotherapy [3-8] historically, advanced-stage JGCTs have behaved aggressively, recurred quickly, and had a poor prognosis. We report the second case of a teenager with Stage III disease treated with fertility sparing surgery and chemotherapy with long-term survival, who many years later delivered four babies.

\section{Case}

A 17 year-old Caucasian female, G0 P0, presented to our hospital in March, 1995, with constipation and increasing abdominal girth. She had menarche at age 12 and had been on oral contraception for one year to regulate her menstrual cycle. Ultrasound revealed ascites, a 17 $\times 13 \mathrm{~cm}$ complex right adnexal mass, and a normal liver. Chest x-ray

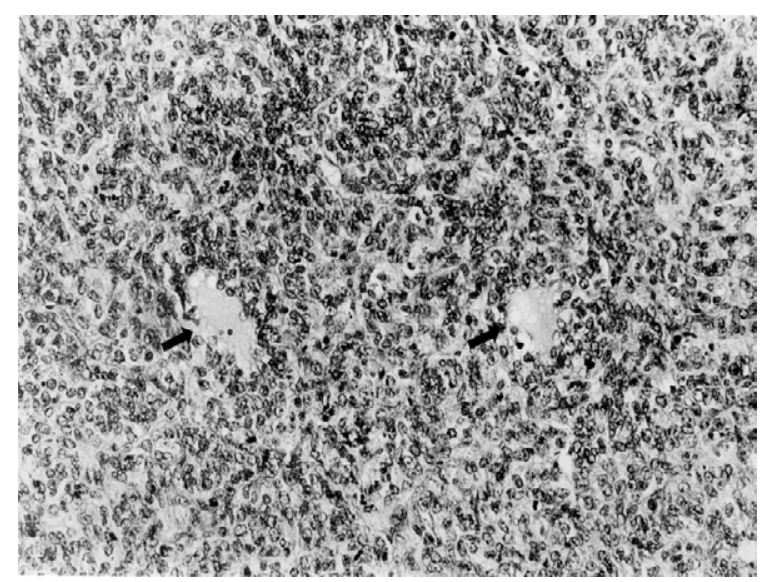

Figure 1: Diffuse arrangement of neoplastic cells which line cystic spaces (arrow) with finely vacuolated contents is seen in a juvenile granulosa cell tumor of the right ovary (hematoxylin and eosin, original magnification $\times 50$ ). was normal. Exploratory laparotomy, right salpingo-oophorectomy, mentectomy, appendectomy, periaortic lymphadenectomy, debulking of extensive intraabdominal tumor, and peritoneal cytology were performed. Fifteen hundred milliters of ascites was present. A 17 $\times 13 \times 7 \mathrm{~cm} 790$ gm right ovarian JGCT with a mitotic index of 13 mitoses per 10 high-power fields was found (Figures 1 and 2). Multiple intraabdominal metastases, including a $2 \times 1 \mathrm{~cm}$ metastasis on the right hemidiaphragm, a $4 \times 3 \mathrm{~cm}$ mass in the left pericolic gutter, a $2 \times 3$ $\mathrm{cm}$ tumor on the falciform ligament, and multiple omental metastases

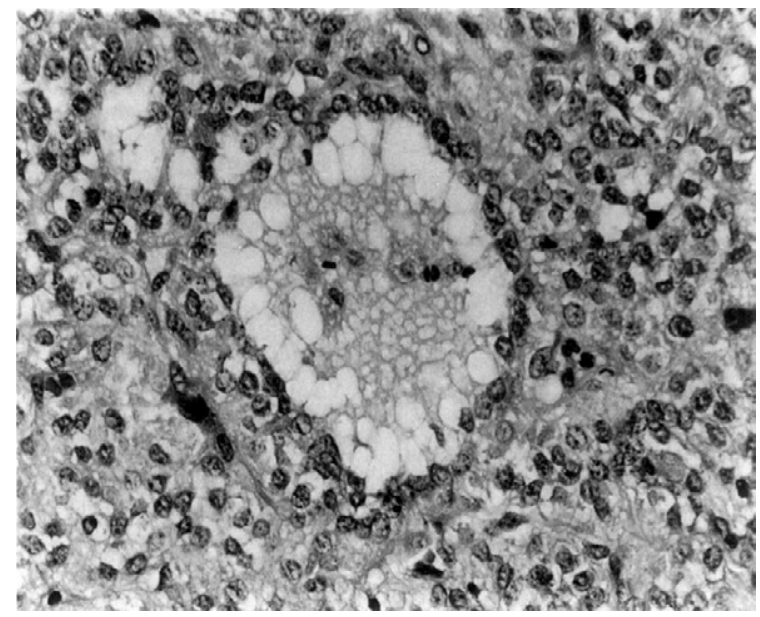

Figure 2: Follicle formation in a juvenile granulosa cell tumor contains vacuolated secretion. Tumor cells contain abundant cytoplasm. Nuclei demonstrate vesicular chromatin rather than the characteristic nuclear grooves commonly seen in adult granulosa cell tumors (hematoxylin and eosin, original magnification $\times 100)$.

*Corresponding author: Powell JL, Departments of Obstetrics and Gynecology, Surgery, Pathology New Hanover Regional Medical Center, 10 Crane Street, Wrightsville Beach, North Carolina 28480, USA, Tel: 910-2566812; E-mail: john.powellatwb@att.net

Received May 19, 2015; Accepted June 20, 2015; Published June 22, 2015

Citation: Powell JL, Kotwall CA, Shiro BC (2015) Multiple Successful Pregnancies Following Fertility-Sparing Surgery for Advanced Ovarian Cancer. J Clin Case Rep 5: 542. doi:10.4172/2165-7920.1000542

Copyright: @ 2015 Powell JL, et al. This is an open-access article distributed under the terms of the Creative Commons Attribution License, which permits unrestricted use, distribution, and reproduction in any medium, provided the original author and source are credited. 
ranging in size from 1 to $3 \mathrm{~cm}$ were excised. Tumor also involved the appendix $(2.4 \times 1.5 \times 1.4 \mathrm{~cm})$. The pelvic and periaortic lymph nodes were not enlarged or suspicious for metastic neoplasm. The uterus, left fallopian tube and left ovary were normal. The cell block on the ascitic fluid was positive for malignant cells. All gross tumor was removed so the surgical result was considered optimal. The liver appeared normal. She was placed in FIGO Stage IIIC. CA- 125 was 76 and total inhibin was 12.0. (Normal levels: CA-125 less than 35 units per ml; total inhibin less than $5 \mathrm{ng} / \mathrm{L}$ ). Postoperative serum estrogen levels were normal. Six cycles of intravenous chemotherapy consisting of carboplatin $400 \mathrm{mg} /$ $\mathrm{m}^{2}$ on day 1 and etoposide $120 \mathrm{mg} / \mathrm{m}^{2}$ on days $1-3$ were administered every 4 weeks without hematologic toxicity. Carboplatin was chosen rather than cisplatin to reduce toxicity. The tumor markers normalized for 1 year. Thirteen months after completion of her initial chemotherapy, she presented with epigastric abdominal pain and a tender mass in the upper abdomen. A CT scan of the abdomen and pelvis revealed an 8.7 $\mathrm{cm}$ mass involving the left hepatic lobe of the liver and a $4.5 \mathrm{~cm}$ mass contiguous with the inferior aspect of the spleen. CA-125 was 45 and total inhibin was 5.7. Subsequently, assays were developed to measure dimeric inhibin $\mathrm{A}$ and $\mathrm{B}$.

In September, 1996, she underwent exploratory laparotomy and excision of the two tumor masses from the liver and spleen. No other foci of tumor were seen. She was treated with six cycles of intravenous chemotherapy consisting of bleomycin 30 units over 24 hours and paclitaxel $175 \mathrm{mg} / \mathrm{m}^{2}(315 \mathrm{mg})$ over 3 hours at monthly intervals based on drug resistant assays and 3 published articles on the efficacy of bleomycin for these tumors. Her CA-125 and inhibin levels normalized in October 1996 and remained normal for 17 years. She had normal menses for 3 years while on oral contraceptives, but later needed Clomid to get pregnant. A male infant was born in November, 2000 , at 36 weeks gestation by cesarean section weighing $2335 \mathrm{gm}$. The infant was diagnosed with Cornelia de Lange Syndrome (also known as Bushy Syndrome and Amsterdam Dwarfism). This genetic disorder is due to spontaneous mutations of genes on chromosomes 5,10 , and $\mathrm{X}$ and was not felt to be related to the prior chemotherapy. No tumor was seen at the time of cesarean delivery. Six years later, a twin pregnancy was achieved with the use of follicle stimulating hormone and human chorionic gonadotropin injections. In November, 2007, she delivered normal fraternal twins (a male weighing $2070 \mathrm{gm}$ and a female weighing $2466 \mathrm{gm}$ ) by cesarean section at 36 weeks gestation. No tumor was seen at that time. The liver was normal in appearance and to palpation.

Seventeen years after her original diagnosis and 5 years after the birth of her twins, she presented with epigastric pain. A CT scan of the abdomen and pelvis revealed recurrent tumors in the left lobe of the liver $(8.8 \times 8.4 \times 6.5 \mathrm{~cm}$ and $4.0 \times 2.6 \times 2.2 \mathrm{~cm})$, in the tail of the pancreas $(2.7 \times 2.6 \times 2.3 \mathrm{~cm})$, and in the wall of the gastric antrum $(4.7 \times 2.8 \mathrm{~cm})$. Preoperative Inhibin A was 16.8, Inhibin B was 1936.2, and CA-125 was 12. (Normal levels: premenopausal women $150 \mathrm{ng} / \mathrm{L}$ for inhibin A and $200 \mathrm{ng} / \mathrm{L}$ for inhibin B; in postmenopausal women, values of less than $5 \mathrm{ng} / \mathrm{L}$ for inhibin $A$ and less than $15 \mathrm{ng} / \mathrm{L}$ for inhibin $B$ are considered normal) She underwent exploratory laparotomy, left hepatic lobectomy, partial pancreatectomy, partial gastrectomy, and cholecystectomy. All gross tumor was removed. Microscopically the tumor had taken on the appearance of an adult granulosa cell tumor. This was confirmed by a positive inhibin immuno-histochemical stain, the presence of Call-Exner bodies and nuclear grooves (Figure 3). The hepatoduodenal and pericolic lymph nodes were negative for tumor and the gallbladder showed mild cholecystitis. Five weeks postoperatively, she was started on intravenous chemotherapy. The first cycle consisted of paclitaxel $175 \mathrm{mg} / \mathrm{m}^{2}(320 \mathrm{mg})$ over 3 hours and bleomycin 30 units

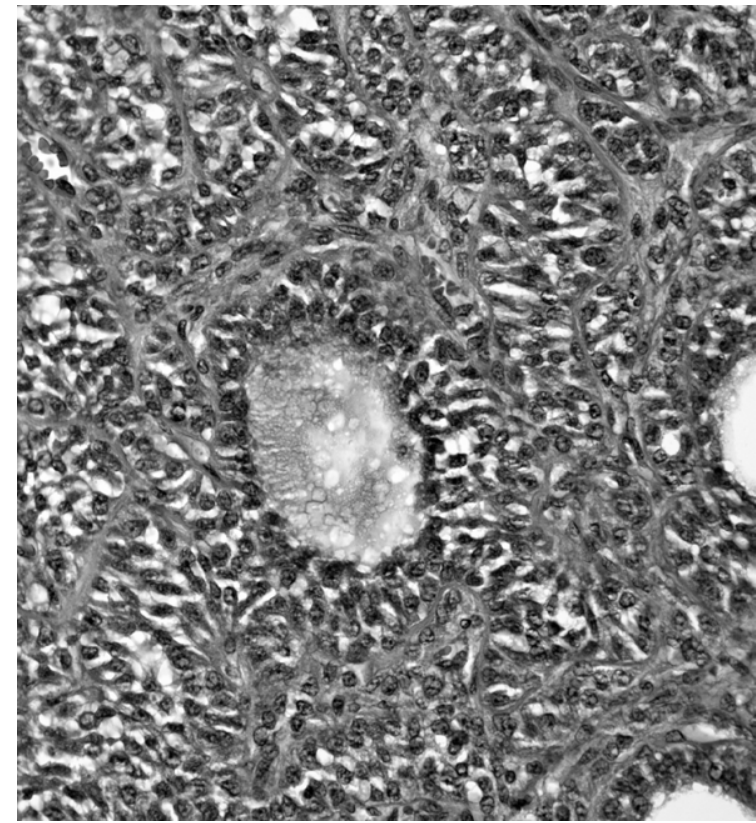

Figure 3: Diffuse arrangement of tumor cells with pale nuclei and a Call-Exner body. (hematoxylin and eosin, original magnification $x 100$ ).

push. Three subsequent cycles consisted of paclitaxel $175 \mathrm{mg} / \mathrm{m}^{2}(320$ $\mathrm{mg})$, bleomycin 30 units, and carboplatin AUC $6(650 \mathrm{mg})$ based on chemo sensitivity and resistant assays. Three weeks after her last chemotherapy, her labs revealed Inhibin a 1, Inhibin B 2.6, and CA-125 was 7. A PET scan was negative. She is currently doing well three years after her last treatment. In March, 2014, she achieved a spontaneous pregnancy without fertility enhancing drugs. In December, 2014, a cesarean section delivery resulted in the birth of a healthy $3260 \mathrm{gm}$ girl. Exploration of the abdomen at that time showed no evidence of tumor.

\section{Discussion}

Granulosa cell tumors of the ovary are rare, constituting $2 \%$ of all ovarian tumors and occur mostly in postmenopausal adult women (95\%). In this age group irregular uterine bleeding is the most common manifestation due to endometrial hyperplasia or, rarely welldifferentiated endometrial adenocarcinoma. Juvenile granulosa cell tumor is much rarer (5\%) and differs from the adult type in clinical and pathologic features, as well as biological behavior (Table 1). JGCT is usually associated with estrogen production and the tumor leads to endocrine symptoms, such as isosexual pseudo-precocity in prepubertal girls and manifests as abdominal pain and swelling in older children. Since the majority of JGCTs are unilateral encapsulated stage IA tumors, conservation of the contralateral ovary and uterus is possible in patients desirous of preserving fertility after proper staging and unilateral adenectomy. Contralateral ovarian involvement is

\begin{tabular}{|c|c|}
\hline Adult GCT & Juvenile GCT \\
\hline Less than 1\% prepubertal & $50 \%$ prepubertal \\
\hline Usual after 30 years & Rare after 30 years \\
\hline $\begin{array}{c}\text { Follicles usually regular without mucin; } \\
\text { Call-Exner bodies common }\end{array}$ & $\begin{array}{c}\text { Follicles often irregular containing mucin; } \\
\text { Call- Exner bodies rare }\end{array}$ \\
\hline Nuclei pale, commonly grooved & Nuclei dark, rarely grooved \\
\hline Luteinization infrequent & Luteinization frequent \\
\hline Recurrence rarely early, often very late & Recurrence typically early \\
\hline
\end{tabular}

Table 1: Adult vs. juvenile granulosa cell tumor (GCT). 
uncommon (3\%) and wedge biopsy is not recommended if the ovary appears grossly normal. Chemotherapy is not required for patients with Stage IA tumors. Their survival with surgery alone is $99 \%$. The clinical stage at the time of diagnosis is considered the most important prognostic factor. Stage III disease carries a poor prognosis with a 5 -year survival of $0-22 \%$ [9-11]. The only absolute indicator of poor prognosis is the presence of extraovarian spread at the time of initial diagnosis. Possible prognostic factors other than stage that emerge in some studies, but not in others, include tumor rupture, age at diagnosis, tumor size, mitotic index, cellular atypia, capsular and lymphatic invasion, and DNA ploidy [12-14].

Therapeutic decisions for patients with advanced stages of JGCTs are difficult and controversial. Standard therapy has been total abdominal hysterectomy, bilateral salpingo-oophorectomy, and removal of as much tumor as possible safely. Since sex cord stromal tumors tend to present at a younger age, fertility-sparing procedures are an important consideration. Some authors have suggested that fertility-sparing procedures may be offered to young patients who strongly desire future fertility. Such recommendations have mainly been based on expert opinions or limited subset analysis of small studies from single institutions. For example, in a series of 51 women with stage I SCST, 12 women underwent fertility-sparing surgery with 3 recurrences. It may be difficult to make strong conclusions on the safety of a fertilitysparing approach given the limited size of these studies. In one study of 132 patients younger than 50 diagnosed with stage I disease, 61 (46\%) underwent standard surgical treatment including a hysterectomy while 71 (54\%) had a uterine-sparing procedure. The prognosis for both groups was extremely favorable with equivalent 5 -year survivals of $97 \%$ and $98 \%$. These data suggest that uterine-sparing surgery may be a safe alternative approach in the surgical management of these young patients. In our opinion in treating teenagers with advanced stage JGCT, as in earlier stages, the uterus, opposite fallopian tube, and ovary can be preserved if free of metastatic tumor. It has been our experience that this conservative approach does not adversely affect survival and that these patients can subsequently have normal pregnancies. Patients with advanced stage JGCT should undergo cytoreductive surgery to remove as much of the tumor and its metastases as possible. The staging operation should include unilateral oophorectomy or salpingo- oophorectomy, total omentectomy, resection of any metastatic lesions from the peritoneal surfaces or from the intestines, pelvic and periaortic lymphadenectomy, appendectomy, and peritoneal cytology. If the ipsilateral fallopian tube is not involved with tumor, it can be spared, as illustrated in a case mentioned later in this discussion. Pathology review by an expert in gynecologic pathology as a send-out to another institution, if not available locally is recommended to ensure the correct diagnosis of this rarely encountered neoplasm. Single alkylating agents have been used in the past, producing a $25 \%$ partial response rate $[15,16]$. Regimens reported to date are noted in Table 2. Combination chemotherapy should be initiated promptly postoperatively. There has been no consistently effective regimen in these patients, although anecdotal cases and small series have reported successes with either regimens of cisplatin, vinblastine, and bleomycin (PVB); methotrexate, actinomycin D, and cyclophosphamide (MAC); cisplatin and doxorubicin; ifosfamide, adriamycin, vincristine, and actinomycin D; carboplatin and etoposide; and carboplatin, bleomycin, and paclitaxel; and bleomycin, etoposide, and cisplatin (BEP) [3-8,13,17] For these patients with advanced-stage JGCT or recurrence, the best treatment is yet to be determined; although, the highest activity has been seen with the PVB and BEP regimens.

The treatment of recurrent disease with hormonal therapy is an option, but experience is limited. Schwartz et al. reported the presence of estrogen and progesterone receptors in GCTs [18]. Those investigators treated their patient, who presented with advanced recurrent disease and receptor-positive tumor, with oral progestin, and her disease was stabilized for 10 months. Her disease was again stabilized on tamoxifen. Malik and Slevin reported 2 patients treated with high doses of medroxyprogesterone acetate who responded with prolonged remissions after documented widespread recurrence [19]. Briasoulis et al. reported a PR with megestrol acetate in an elderly woman with GCT and lung metastases lasting for 20 months who had a recurrence after carboplatin chemotherapy [20]. Treatment with a gonadotropinreleasing hormone (GnRH-goserelin) analog achieved a transient partial response in 1 patient who had a recurrence after cytotoxic platinum-based chemo therapy [21] Leuprolide acetate yielded two partial responses of 4 and 12 months, respectively, in five patients with advanced GCT [22]. Radiotherapy can induce a clinical response with

\begin{tabular}{|c|c|c|c|}
\hline Year & (n) number of cases & Primary author & Regimen \\
\hline 1974 & 12 & Malkasian [15] & cyclophosphamide \\
\hline 1976 & 2 & Schwartz [16] & $\begin{array}{l}\text { cyclophosphamide+actinomycin+ } \\
\text { 5-fluorouracil }\end{array}$ \\
\hline 1978 & 1 & DiSaia [30] & doxorubicin \\
\hline 1980 & 13 & Slayton [31] & $\begin{array}{l}\text { actinomycin+ cyclophosphamide+ } \\
\text { 5-fluorouracil }\end{array}$ \\
\hline 1982 & 2 & Jacobs [32] & cisplatin+ doxorubicin \\
\hline 1983 & 1 & Camlibel [33] & cisplatin+ cyclophosphamide+ doxorubicin \\
\hline 1984 & 2 & Neville [34] & altretamine+cisplatin \\
\hline 1986 & 1 & Kaye [35] & cisplatin+ cyclophosphamide+ doxorubicin \\
\hline 1986 & 11 & Colombo [3] & bleomycin+ cisplatin+vinblastine \\
\hline 1987 & 8 & Gershenson [12] & cisplatin+ cyclophosphamide+ doxorubicin \\
\hline 1988 & 4 & Vassal [4] & methotrexate+actinomycin+ cyclophosphamide \\
\hline 1993 & 1 & Powell [5] & methotrexate+actinomycin+chlorambucil \\
\hline 1995 & 1 & Wessalowski [6] & $\begin{array}{l}\text { ifosfamide+ doxorubicin+vincristine+actinomycin, then } \\
\text { carboplatin+etoposide+ ifosfamide }\end{array}$ \\
\hline 1996 & 6 & Gershenson [13] & bleomycin+cisplatin+etoposide \\
\hline 1997 & 1 & Powell [7] & carboplatin+etoposide \\
\hline 1999 & 48 & Homesley [17] & bleomycin+cisplatin+etoposide \\
\hline 2001 & 1 & Powell [8] & bleomycin+paclitaxel \\
\hline
\end{tabular}

Table 2: Chemotherapy for granulosa cell tumors. 
occasional long-term remission in patients with persistent or recurrent GCT of the ovary $[23,24]$.

In selected cases, conservation of the uninvolved fallopian tube, ovary, and uterus in patients with advanced-stage JGCT may not compromise survival. Because total abdominal hysterectomy and bilateral salpingo-oophorectomy are the standard surgical procedures in patients with advanced ovarian cancer, physicians should understand that the conservative approach should be considered only in selected cases, after proper assessment of the risks and benefits and thorough counseling of the patient and her family. Nevertheless, cure without deformity or loss of function must ever be surgery's highest ideal.

Powell et al. [5,7] reported a 13-year-old treated with right oophorectomy, omentectomy, appendectomy, excision of tumor from bowel mesentery, peritoneal washings, and three cycles of MAC (methotrexate $8 \mathrm{mg} / \mathrm{m}^{2} /$ day for 5 days, actinomycin $0.5 \mathrm{mg} /$ day for 5 days, chlorambucil $4 \mathrm{mg} / \mathrm{m}^{2} /$ day for 5 days) chemotherapy repeated monthly for Stage III JGCT. She was 27 weeks pregnant at the time of surgery and refused chemotherapy until after delivery of a normal infant at term without complications. She subsequently delivered 2 more normal infants at term without complications 6 and 9 years later. She was followed for 12 years and was clinically free of disease. Because of the propensity of GCT to recur years later after initial diagnosis, prolonged surveillance with serial physical examination, and serum tumor markers, such as inhibin, CA-125, estradiol, and mullerian inhibiting substance are reasonable [25-29]. Inhibin is considered the best marker for monitoring women with GCTs [25-27]. Boggess et al. [27] determined that serum inhibin levels correlated directly with tumor burden, treatment response, and recurrent disease. Because it is a convenient marker for granulosa cell activity, antimullerian hormone has been used as a tool in diagnosing and monitoring GCTs [29].

\section{Conclusion}

Long-term survival in cases of advanced JGCT can happen. Fertility-sparing surgery is appropriate in these young women, but they need long-term follow-up due to the possibility of recurrence.

\section{Acknowledgements}

The authors thank John Bingham Powell for technical assistance in the computer preparation of the manuscript.

\section{References}

1. Young RH, Dudley AG, Scully RE (1984) Granulosa cell, Sertoli-Leydig cell, and unclassified sex cord-stromal tumors associated with pregnancy: a clinicopathological analysis of thirty-six cases. Gynecol Oncol 18: 181-205.

2. Young RH, Dickersin GR, Scully RE (1984) Juvenile granulosa cell tumor of the ovary. A clinicopathological analysis of 125 cases. Am J Surg Pathol 8: 575-596.

3. Colombo N, Sessa C, Landoni F, Sartori E, Pecorelli S, et al. (1986) Cisplatin, vinblastine, and bleomycin combination chemotherapy in metastatic granulosa cell tumor of the ovary. Obstet Gynecol 67: 265-268.

4. Vassal G,Flamant F, Caillaud JM, Demeocq F, Nihoul-Fekete C, et al. (1988) Juvenile granulosa cell tumor of the ovary in children: a clinical study of 15 cases. J Clin Oncol 6: 990-995.

5. Powell JL,Johnson NA, Bailey CL, Otis CN (1993) Management of advanced juvenile granulosa cell tumor of the ovary. Gynecol Oncol 48: 119-123.

6. Wessalowski R,Spaar HJ, Pape H, Willers R, Harms D, et al. (1995) Successfu liver treatment of a juvenile granulosa cell tumor in a 4-year-old child by regional deep hyperthermia, systemic chemotherapy, and irradiation. Gynecol Oncol 57: 417-422.

7. Powell JL,Otis CN (1997) Management of advanced juvenile granulosa cell tumor of the ovary. Gynecol Oncol 64: 282-284.
8. Powell JL,Connor GP, Henderson GS (2001) Management of recurrent juvenile granulosa cell tumor of the ovary. Gynecol Oncol 81: 113-116.

9. Evans MP,Webb MJ, Gaffey TA, Katzmann JA, Suman VJ, et al. (1995) DNA ploidy of ovarian granulosa cell tumors. Lack of correlation between DNA index or proliferative index and outcome in 40 patients. Cancer 75: 2295-2298.

10. Björkholm E, Silfverswärd C (1981) Prognostic factors in granulosa-cell tumors Gynecol Oncol 11: 261-274.

11. Ayhan A,Tuncer ZS, Tuncer R, Mercan R, Yüce K, et al. (1994) Granulosa cell tumor of the ovary. A clinicopathological evaluation of 60 cases. Eur J Gynaecol Oncol 15: 320-324.

12. Gershenson DM, Copeland LJ, Kavanagh JJ, Stringer CA, Saul PB, et al. (1987) Treatment of metastatic stromal tumors of the ovary with cisplatin, doxorubicin, and cyclophosphamide. Obstet Gynecol 70: 765-769.

13. Gershenson DM,Morris M, Burke TW, Levenback C, Matthews CM, et al. (1996) Treatment of poor-prognosis sex cord-stromal tumors of the ovary with the combination of bleomycin, etoposide, and cisplatin. Obstet Gynecol 87 : 527-531.

14. Koukourakis GV,Kouloulias VE, Koukourakis MJ, Zacharias GA, Papadimitriou C, et al. (2008) Granulosa cell tumor of the ovary: tumor review. Integr Cancer Ther 7: 204-215.

15. Malkasian GD Jr, Webb MJ, Jorgensen EO (1974) Observations on chemotherapy of granulosa cell carcinomas and malignant ovarian teratomas. Obstet Gynecol 44: 885-888.

16. Schwartz PE, Smith JP (1976) Treatment of ovarian stromal tumors. Am J Obstet Gynecol 125: 402-411.

17. Homesley HD,Bundy BN, Hurteau JA, Roth LM (1999) Bleomycin, etoposide and cisplatin combination therapy of ovarian granulosa cell tumors and othe stromal malignancies: A Gynecologic Oncology Group study. Gynecol Oncol 72. $131-137$

18. Schwartz PE, MacLusky N, Sakamoto H, Eisenfeld A (1983) Steroid-receptor proteins in nonepithelial malignancies of the ovary. Gynecol Oncol 15: 305-315.

19. Malik ST,Slevin ML (1991) Medroxyprogesterone acetate (MPA) in advanced granulosa cell tumours of the ovary--a new therapeutic approach? $\mathrm{Br} \mathrm{J}$ Cancer 63: 410-411.

20. Briasoulis E, Karavasilis V, Pavlidis N (1997) Megestrol activity in recurrent adult type granulosa cell tumour of the ovary. Ann Oncol 8: 811-812.

21. Martikainen H,Penttinen J, Huhtaniemi I, Kauppila A (1989) Gonadotropinreleasing hormone agonist analog therapy effective in ovarian granulosa cell malignancy. Gynecol Oncol 35: 406-408.

22. Fishman A,Kudelka AP, Tresukosol D, Edwards CL, Freedman RS, et al. (1996) Leuprolide acetate for treating refractory or persistent ovarian granulosa cell tumor. J Reprod Med 41: 393-396.

23. Wolf JK,Mullen J, Eifel PJ, Burke TW, Levenback C, et al. (1999) Radiation treatment of advanced or recurrent granulosa cell tumor of the ovary. Gynecol Oncol 73: 35-41.

24. Hauspy J,Beiner ME, Harley I, Rosen B, Murphy J, et al. (2011) Role of adjuvant radiotherapy in granulosa cell tumors of the ovary. Int $\mathrm{J}$ Radiat Oncol Biol Phys 79: 770-774.

25. Lappöhn RE,Burger HG, Bouma J, Bangah M, Krans M, et al. (1989) Inhibin as a marker for granulosa-cell tumors. N Engl J Med 321: 790-793.

26. Hildebrandt RH,Rouse RV, Longacre TA (1997) Value of inhibin in the identification of granulosa cell tumors of the ovary. Hum Pathol 28: 1387-1395.

27. Boggess JF,Soules MR, Goff BA, Greer BE, Cain JM, et al. (1997) Serum inhibin and disease status in women with ovarian granulosa cell tumors. Gynecol Oncol 64: 64-69.

28. Makar AP,Kristensen GB, Kaern J, Børmer OP, Abeler VM, et al. (1992) Prognostic value of pre- and postoperative serum CA 125 levels in ovarian cancer: new aspects and multivariate analysis. Obstet Gynecol 79: 1002-1010.

29. Hill BJ,Morrell TJ, Zhang MM, Norian JM (2013) Utility of antimüllerian hormone level obtained for infertility assessment for alerting to ovarian tumor. Obstet Gynecol 121: 454-457.

30. Disaia P, Saltz A, Kagan AR, Rich W (1978) A temporary response of recurrent granulosa cell tumor to adriamycin. Obstet Gynecol 52: 355-358. 
Citation: Powell JL, Kotwall CA, Shiro BC (2015) Multiple Successful Pregnancies Following Fertility-Sparing Surgery for Advanced Ovarian Cancer. J Clin Case Rep 5: 542. doi:10.4172/2165-7920.1000542

31. Slayton R, Brady L, Johnson G, Blessing JA (1980) Radiotherapy or chemotherapy in malignant stromal tumors of the ovary. Proc Am Soc Clin Oncol 430: (abstract C-444).

32. Jacobs AJ, Deppe G, Cohen CJ (1982) Combination chemotherapy of ovarian granulosa cell tumor with cis-platinum and doxorubicin. Gynecol Oncol 14: 294297.

33. Camlibel FT, Caputo TA (1983) Chemotherapy of granulosa cell tumors. Am J Obstet Gynecol 145: 763-765.
34. Neville AJ, Gilchrist KW, Davis TE (1984) The chemotherapy of granulosa cell tumors of the ovary: experience of the Wisconsin Clinical Cancer Center. Med Pediatr Oncol 12: 397-400.

35. Kaye SB, Davies E (1986) Cyclophosphamide, adriamycin, and cis-platinum for the treatment of advanced granulosa cell tumor, using serum estradiol as a tumor marker. Gynecol Oncol 24: 261-264. 